Игорь Иванович КАЛИГАНОВ 


\section{ДРЕВНЕЙШАЯ \\ ДАТИРОВАННАЯ РУКОПИСНАЯ КНИГА У ВОСТОЧНЫХ СЛАВЯН: ОСТРОМИРОВО ЕВАНГЕЛИЕ}

\section{Аннотация:}

В статье рассказывается о древнейшей восточнославянской датированной рукописи: Остромировом Евангелии 1056-1057 гг. Оно получило свое название по имени новгородского посадника Остромира - доверенного лица киевского князя, назначенного им для управления городом. Скорее всего, Остромир вложил это роскошное Евангелие в только что выстроенный собор Св. Софии - главный храм Северо-Западной Руси. У этой драгоценной рукописи была переменчивая судьба: кроме Новгорода, она побывала в Москве и Санкт-Петербурге, принадлежала русским императорам и императрицам, пока не была передана в начале XIX в. на библиотечное хранение. Находящееся ныне в Российской национальной библиотеке Санкт-Петербурга Остромирово Евангелие служит прекрасным образцом для изучения литературно-книжного языка Древней Руси, славяно-русской палеографии и искусства иллюминации рукописных книг: инициалов, заставок и миниатюр. Дальним протографом Остромирова Евангелия, возможно, послужила одна из болгарских рукописей из Великого Преслава - столицы Болгарии в конце IX-X вв.

\section{Ключевые слова:}

Древнейшая восточнославянская датированная рукопись, Новгород, посадник Остромир, отдаленный болгарский протограф.

\section{Abstract: I.I. Kaliganov "The Oldest EAST SlaVic DATED MANUSCRIPT: OSTROMIR Gospel”.}

The article talks about the oldest East Slavic dated manuscript: the Ostromir Gospel 1056-1057. It received its name from that of the Novgorod ruler Ostromir, a trusted person of the Kievan Prince appointed by him to manage the city. Most likely, Ostromir presented this luxurious gospel to the newly built cathedral of St. Sofia, the main church of North-West Rus'. This precious manuscript had a chequered fate: in addition to Novgorod, it was kept in Moscow and St. Petersburg, belonged to Russian emperors and empresses until it was transferred in the early 19th century to library storage and is located now in the Russian National Library of St. Petersburg. Ostromir Gospel serves as an excellent model for studying the literary and book language of old Rus', SlavoRussian paleography and the art of illuminating handwritten books: initials, screensavers and miniatures. The distant protograph of Ostromir Gospel may have been one of the Bulgarian manuscripts from Great Preslav, the capital of Bulgaria at the end of the 9 th -10 th centuries.

\section{Keywords:}

The oldest East Slavic dated manuscript, Novgorod, city ruler Ostromir, distant Bulgarian protograph.

1 Работа выполнена при финансовой поддержке РФФИ (грант № 18-512-76004). 
$\mathrm{O}$ стромирово Евангелие (1056-1057) - древнейшая датированная рукопись у восточных славян размером 35, 5 х 29 см., на 294 пергаменных листах. Писана крупным уставом в две колонки, каждая из которых имеет в среднем по 18 строк. Размер текстового поля 20 х 24 см., размеры букв - от 5 до 7 мм. Рукопись богато украшена, в ней имеются миниатюры с изображениями Евангелистов, заставки, а также многочисленные крупные, средние и мелкие инициалы. Наиболее часто в тексте встречаются крупные инициалы «В», иногда зооморфные или антропоморфные. В украшениях использованы киноварь, творенное золото, зеленая, красная, коричневая, желтая и синяя краски. По содержанию рукопись представляет собой краткое (апракосное) Евангелие, основную часть (лл. 2-204) которого составляют ежедневные чтения на 50 дней от Пасхи до Пятидесятницы, а также субботние и воскресные чтения на последующие недели года. Помещены в ней и чтения по Месяцеслову с сентября и на разные случаи жизни: на освящение церкви, «в победу царю на брани» и др.

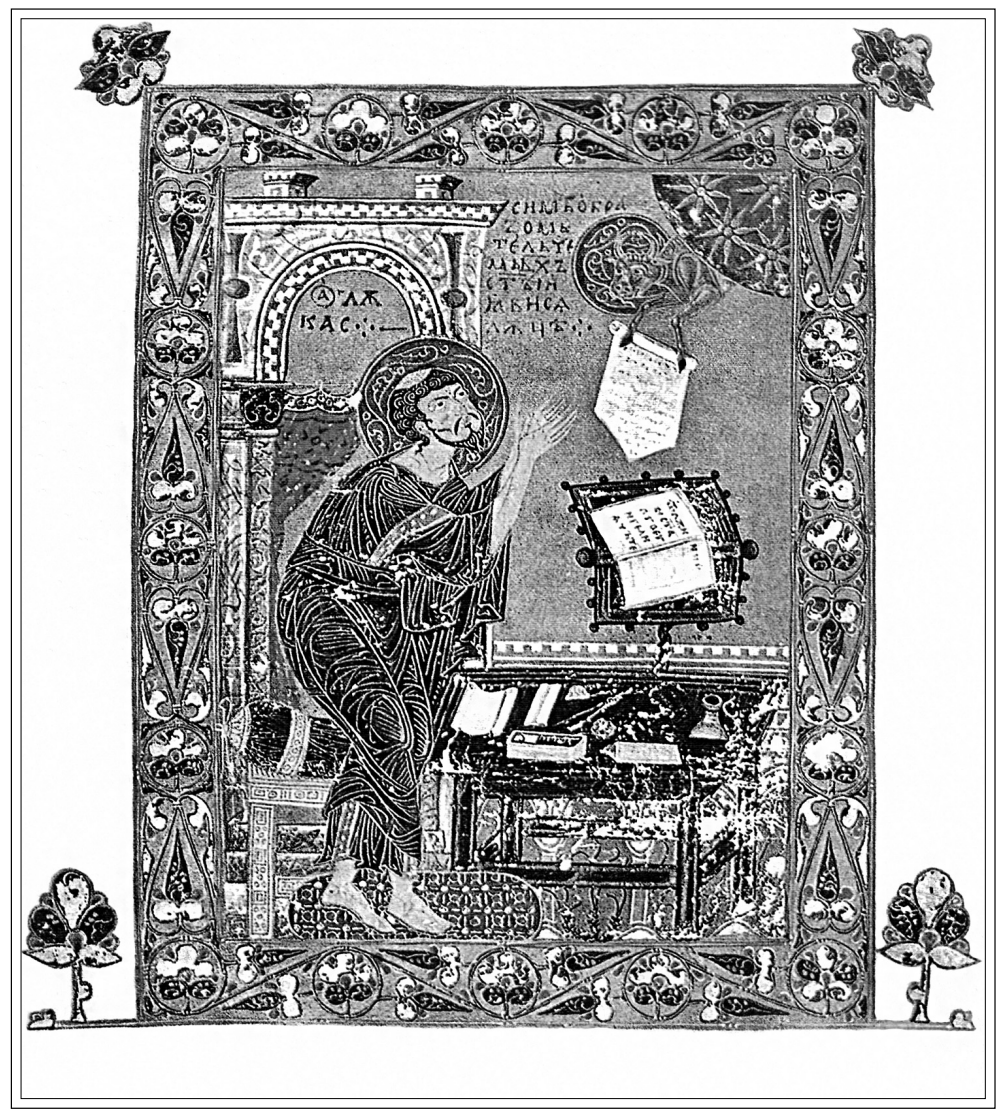

Евангелист Лука.

Миниатюра Остромирова Евангелия 
На лл. 293-293 об. Евангелия находится запись, проясняющая обстоятельства появления данного манускрипта на свет. Судя по содержащимся в ней данным, над его созданием в течение почти семи месяцев (с 21 октября 1056 г. по 12 мая 1057 г.) трудился диакон Григорий. Он принялся за работу над ним по распоряжению сына Ярослава Мудрого киевского великого князя Изяслава. Манускрипт предназначался для близкого княжьего родственника, новгородского посадника Остромира. В Киевской Руси посадничество в Новгороде - втором по величине городе государства - было тогда очень высокой должностью. Посадник являлся в Новгороде главным лицом, его «сажал» править городом киевский князь, чтобы тот представлял в нем княжеские интересы. Киевскому назначенцу принадлежала в нем вся полнота власти: он вершил суд, ведал обороной и торговыми отношениями Новгорода с другими русскими и чужеземными городами. Диакон Григорий называет посадника языческим мирским именем Остромир, хотя и приводит имя, данное тому в крещении, - Иосиф. В конце записи писец желает здоровья не только Остромиру, но и супруге его Феофане, их детям и женам детей. Одновременно Григорий извещал, что старался работать над рукописью по возможности тщательнее, и просил не клясть его за обнаруженные ошибки, а исправлять их и благословлять - правило, к которому призывал апостол Павел.

Остромир происходил из знатного рода: его дед Добрыня приходился дядей крестителю Руси князю Владимиру и послужил прообразом былинного богатыря Добрыни Никитича. Что же касается самого Остромира, то он был двоюродным дядей упомянутого великого князя Изяслава. Изготовленное для него роскошное Евангелие, скорее всего, предназначалось для помещения его на престоле только что выстроенного в Новгороде (1045-1050) собора Св. Софии - главном храме Северо-Западной Руси. После получения Евангелия Остромир-Иосиф властвовал сравнительно недолго. Через три года он погиб, встав во главе новгородской дружины во время похода на чудь.

Неизвестно, как долго затем Остромирово Евангелие находилось в Новгороде. В Москву его мог привести известный любитель книжности новгородский архиепископ Макарий, ставший при Иване Грозном в 1542 г. митрополитом Московским - т.е. главой Русской Православной церкви. Или же это могло случиться позднее во время карательного похода на Новгород в 1570 г. самого Ивана Грозного. Во всяком случае, в начале XVIII в. Остромирово Евангелие уже хранилось в Воскресенской церкви из комплекса Верхнеспасского собора, являвшегося домовым храмом русских царей при Теремном дворце Московского Кремля. В 1720 г. манускрипт передали Петру I, и вместе с другими книгами он оказался в Санкт-Петербурге, принадлежа по очереди членам русской Императорской фамилии. В 1806 г. российский император Александр I распорядился передать рукопись в санкт-петербургскую Императорскую публичную библиотеку (в настоящее время - Российская Национальная библиотека), где она хранится 
и поныне под шифром F.n.1.5. К сожалению, роскошный золоченый оклад Остромирова Евангелия, изготовленный в 1851 г. на средства московских купцов, едва не привел рукопись к гибели. В 1932 г. некий вандал-водопроводчик разбил витрину, где она хранилась, ободрал драгоценный переплет и забросил ее на шкаф. После обнаружения изуродованной рукописи ее решили заново не переплетать и поместили на сохранение в дубовый ларец.

Текст Остромирова Евангелия неоднократно издавался. Начало этому положил русский ученый А.Х. Востоков, в 1843 г. осуществивший наборное издание текста памятника в сопровождении краткой грамматики древнерусского языка и подстрочно-

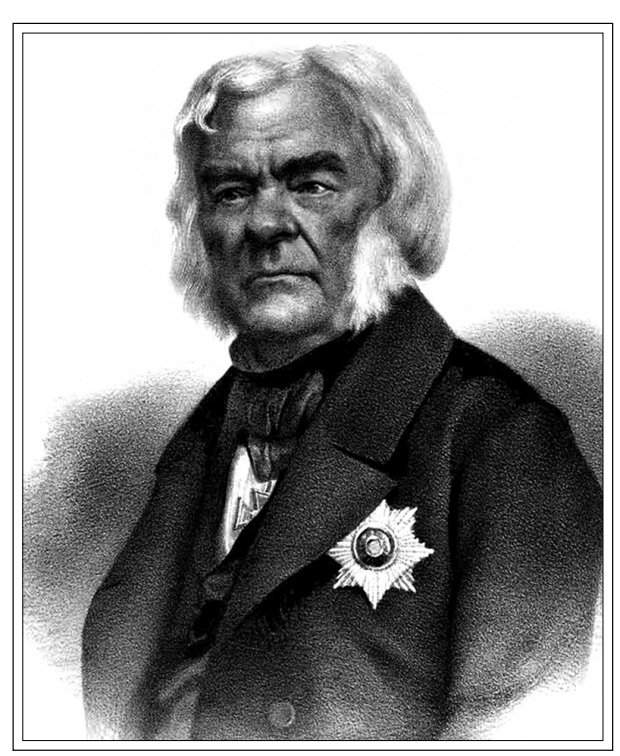

А.Х. Востоков - первый издатель Остромирова Евангелия го греческого текста. Около четырех десятилетий спустя на средства русского купца Ильи Кирилловича Савинкова было выпущено факсимильное издание данной раритетной рукописи, важное для ее палеографического изучения. Следует отметить и дорогое подарочное издание Остромирова Евангелия в цвете, отпечатанное в Ленинграде в 1988 г. в связи 1000-м юбилеем крещения Руси. На основе текста памятника создавались и продолжают создаваться грамматики и словари старославянского языка. Язык рукописи отражает черты архаичного литературно-книжного древнецерковнославянского языка, который распространялся тогда в Киевской Руси через переводную болгарскую книжность. Диакон Григорий, вероятно, переписывал текст, имеющий болгарское происхождение. Его отдаленным протографом, видимо, послужила рукопись начала Х столетия, созданная в период правления болгарского царя Симеона Великого, которая затем неоднократно переписывалась, приобретая новые языковые нюансы. В языке Остромирова Евангелия наблюдаются местные русские особенности, которые позволяют говорить о наличии у части восточных славян в середине XI в. русской редакции старославянского языка. Это видно, например, по случаям использования полногласия, смешения древнеславянских носовых гласных $\mathbf{A}, \mathbf{H}, \boldsymbol{\mathbf { z }}$ и $\mathbf{\boldsymbol { K }}$ с О, Ю и $\boldsymbol{Я}$ или употребления редуцированных $\mathbf{P}$ и Л вместо слоговых $\mathbf{P} \mathbf{b}, \mathbf{P Ъ}$ и ЛЬ. В украшениях рукописи чувствуется связь не только с художественными традициями Византии и Болгарии, но и Западной Европы.

В результате тщательного кодикологического и палеографического изучения Остромирова Евангелия было установлено, что в его создании 
принимали участие, по крайней мере, три писца и то, что особые «экофонические» (музыкальные) значки проставлялись в нем на нужных местах далеко не всегда. В целом научное исследование рукописи нельзя считать завершенным. До сих пор не решен, например, спорный вопрос о месте ее создания, и доводы сторонников Киева и Новгорода остаются на сегодня приблизительно равными. Дальнейшее изучение памятника, наверняка, приведет к новым и, возможно, неожиданным научным открытиям.

Единственное, что не вызывает сомнение, так это огромное значение Остромирова Евангелия для истории древнейшей письменности у восточных и Южных славян. Не случайно в 2011 г. ЮНЕСКО внесло Остромирово Евангелие в список «Память мира» - реестр, в который обычно включают наиболее значимые памятники мирового культурного наследия.

\section{ЛИТЕРАТУРА}

Владымевская Т.Ф. Музыкальная культура Древней Руси. М., 2006.

жуковская Л.П. Текстология и язык древнейших славянских памятников. M., 1976.

Загребин В.M. Исследования памятников южнославянской и древнерусской письменности. М.: СПб., 2006.

Gardzaniti M. Altslavische Version der Evangelien. Köln, Weimar, Wien, 2001.

\section{СПИСОК ИЛЛЮСТРАЦИЙ}

1. Евангелист Иоанн. Миниатюра Остромирова Евангелия. 1056-1057 гг. Л. 1 об.

2. Заставка перед началом чтений из Евангелия от Иоанна. Миниатюра Остромирова Евангелия. 1056-1057 гг. Л. 2.

3. Евангелист Лука. Миниатюра Остромирова Евангелия. 1056-1057 Гг. Л. 87 об.

4. Евангелист Марк. Миниатюра Остромирова Евангелия. 1056-1057 гг. Л. 126.

5. Крупный антропоморфный инициал «В». Остромирово Евангелие. 1056-1057 гг. Л. 68.

6. Запись писца диакона Григория об обстоятельствах написания Остромирова Евангелия 1056-1057 гг. Л. 293.

7. Запись писца диакона Григория об обстоятельствах написания Остромирова Евангелия 1056-1057 гг. Л. 293 об.

8. Общий вид Верхнеспасского собора - домового храма русских царей при Теремном дворце Московского Кремля, где Остромирово Евангелие находилось в первых десятилетиях XVIII в.

9. Русский ученый А.Х. Востоков (1781-1864), осуществивший в 1843 г. в Санкт-Петербурге первое наборное издание Остромирова Евангелия 1056-1057 гг.

10. Обложка первого наборного издания Остромирова Евангелия 1056-1057 гг., которое в 1843 г. осуществил в Санкт-Петербурге русский ученый А.X. ВостокОв. 